\title{
Cervical Dorsal Rhizotomy Increases Brain-Derived Neurotrophic Factor and Neurotrophin-3 Expression in the Ventral Spinal Cord
}

\author{
Rebecca A. Johnson, ${ }^{1}$ Angela J. Okragly, ${ }^{2}$ Mary Haak-Frendscho, ${ }^{2}$ and Gordon S. Mitchell ${ }^{1}$ \\ ${ }^{1}$ Department of Comparative Biosciences, School of Veterinary Medicine, University of Wisconsin-Madison, Madison, \\ Wisconsin 53706, and 2Department of Neurobiology and Immunology, Promega Corporation, Madison, Wisconsin 53711
}

Although neurotrophic factors have been implicated in several forms of neuroplasticity, little is known concerning their potential role in spinal plasticity. Cervical dorsal rhizotomy (CDR) enhances serotonin terminal density near (spinal) phrenic motoneurons and serotonin-dependent long-term facilitation of phrenic motor output (Kinkead et al., 1998). We tested the hypothesis that selected neurotrophic factors change in a manner consistent with an involvement in this model of spinal plasticity. Brain-derived neurotrophic factor (BDNF), neurotrophin-3 (NT-3), glial cell line-derived neurotrophic factor (GDNF), and transforming growth factor- $\beta_{1}$ (TGF- $\beta_{1}$ ) concentrations were measured (ELISA) in three regions of interest to respiratory control: (1) ventral cervical spinal segments associated with the phrenic motor nucleus (C3-C6), (2) ventral thoracic spinal segments associated with inspiratory intercostal

Spinal neuroplasticity has been widely appreciated only in recent years (Edgerton et al., 1992; Randic, 1996; Liou and Goshgarian, 1997; Neumann and Woolf, 1999). Spinal plasticity has implications in the lifelong adjustments of important motor control systems (e.g., respiration and locomotion) and has potential to promote functional recovery after spinal cord injury. For example, cervical spinal hemisection enhances synaptic efficacy in existing, but functionally ineffective pathways that cross the spinal midline and innervate contralateral phrenic motoneurons (i.e., the "crossed phrenic phenomenon"; Goshgarian and Guth, 1977; Moreno et al., 1992).

Spinal deafferentation also elicits plasticity in descending neurochemical pathways. For example, sensory denervation via dorsal rhizotomy augments descending serotonergic pathways from the raphe nuclei to the spinal dorsal horn (Zhang et al., 1993). Cervical dorsal rhizotomy (CDR; C3-C5) eliminates sensory feedback from the diaphragm and elicits three forms of plasticity, including a slight enlargement of phrenic motoneurons (Zhan et al., 1997), increased serotonergic terminal density in the immediate vicinity of phrenic motoneurons (Kinkead et al., 1998), and an augmentation of serotonin-dependent long-term facilitation of respiratory (phrenic) motor output after episodic hypoxia

\footnotetext{
Received Dec. 27, 1999; revised Feb. 29, 2000; accepted March 14, 2000.

This research was supported by National Institutes of Health grants HL53319, HL36780, and HL03874. We thank Dr. M. Behan for discussions and assistance in analyzing the immunohistochemical data and B. White for technical assistance performing the immunohistochemical procedures.

Correspondence should be addressed to Dr. Gordon S. Mitchell, Department of Comparative Biosciences, School of Veterinary Medicine, University of WisconsinMadison, 2015 Linden Drive West, Madison, WI 53706. E-mail: Mitchell@svm.vetmed.wisc.edu.

Copyright (C) 2000 Society for Neuroscience $\quad 0270-6474 / 00 / 200001-\bullet \$ 15.00 / 0$
}

motor output (T3-T6) and (3) the diaphragm. Tissues were harvested from rats $7 \mathrm{~d}$ after bilateral CDR and compared with sham-operated and unoperated control rats. CDR increased BDNF (110\%; $p=0.002)$ and NT-3 (100\%; $p=0.002)$ in the cervical and NT-3 in the thoracic spinal cord (98\%; $p=0.009)$. GDNF and TGF- $\beta_{1}$ were not altered by CDR in any tissue. Immunohistochemistry localized BDNF and NT-3 to motoneurons and interneurons of the ventral spinal cord. These studies provide novel, suggestive evidence that BDNF and NT-3, possibly through their trophic effects on serotonergic neurons and/or motoneurons, may underlie serotonin-dependent plasticity in (spinal) respiratory motor control after CDR.

Key words: plasticity; spinal; serotonin; respiratory control; phrenic motor nucleus; neurotrophin
(Kinkead et al., 1998). Thus, CDR elicits both morphological and functional plasticity of pathways not associated with primary afferent neurotransmission. Dorsal rhizotomy may also elicit neurochemical (and presumably functional) plasticity in spinal regions distant from the site of denervation (Mitchell et al., 1995; Turner et al., 1997).

Little is known concerning the cellular or molecular mechanisms that underlie spinal plasticity. Neurotrophic factors are implicated in short- and long-term enhancement of synaptic strength in the hippocampus (Kang and Shuman, 1995a,b; Sherwood and Lo, 1999), the formation of ocular dominance columns in the visual cortex (Cabelli et al., 1995; Rossi et al., 1999), and plasticity within the barrel cortex after whisker removal (Singh et al., 1997; Calia et al., 1998). Neurotrophins and other neurotrophic factors, including members of the transforming growth factor- $\beta$ superfamily, and their receptors are located in the spinal cord (Johnson et al., 1996; Yamamoto et al., 1996; DeLeo et al., 1997; Glazner et al., 1998; Dreyfus et al., 1999) and have potent

This article is published in The Journal of Neuroscience, Rapid Communications Section, which publishes brief, peerreviewed papers online, not in print. Rapid Communications are posted online approximately one month earlier than they would appear if printed. They are listed in the Table of Contents of the next open issue of JNeurosci. Cite this article as: JNeurosci, 2000, 0:RC77 (1-5). The publication date is the date of posting online at www.jneurosci.org.

http://www.jneurosci.org/cgi/content/full/4209 
neurotrophic effects on motoneurons (Elliott and Snider, 1996) and serotonergic neurons (Mamounas et al., 1995, 2000).

To determine the potential of selected neurotrophic factors to play a role in spinal plasticity, four neurotrophic factors were studied in a model of selective spinal injury known to result in serotonin-mediated spinal plasticity (Kinkead et al., 1998): cervical dorsal rhizotomy. Protein concentrations of two neurotrophins, brain-derived neurotrophic factor (BDNF) and neurotrophin-3 (NT-3), and two members of the transforming growth factor- $\beta$ superfamily, glial cell line-derived neurotrophic factor (GDNF) and transforming growth factor- $\beta_{1}$ (TGF- $\beta_{1}$ ), were measured in adult rats after CDR.

\section{MATERIALS AND METHODS}

All procedures were approved by the University of Wisconsin Animal Care and Use Committee. Adult male rats (Harlan Sprague Dawley, Colony 236, Oregon, WI), ranging in mass from 248 to $334 \mathrm{gm}$ (mean \pm SD, $284 \pm 18 \mathrm{gm}$ ) were divided into three groups: (1) bilateral CDR from C3 to C6 $(n=6),(2)$ sham-operated (for BDNF, GDNF, and TGF- $\beta_{1}$ assays, $n=2$; for NT-3 assays, $n=6)$, and (3) unoperated controls $(n=$ 6). For GDNF analysis, it was necessary to pool tissues from all four spinal segments from four rats to make one protein determination with the assay used in this study (ELISA). Thus, to achieve $n=6$, it was necessary to perform CDR on 24 rats.

Surgical procedures. Bilateral CDR and sham operations were performed under isoflurane anesthesia after premedication with buprenorphine $(0.3 \mathrm{mg} / \mathrm{kg}$, i.p.). Dorsal laminectomy of cervical vertebrae $2-6$ was completed, and the dura was cut. The dorsal rootlets were isolated from radicular vessels to the extent possible and were cut bilaterally from C3 to C6. Sham surgeries were performed in which the dorsal rootlets were isolated and identified but not transected. The muscles were apposed, and the skin was closed. No evidence of autotomy was observed after surgery in any rat. Rhizotomized and sham-operated rats were recovered for $7 \mathrm{~d}$.

Tissue preparation. Rats were killed with an overdose of pentobarbital and quickly immersed in liquid nitrogen for $8 \mathrm{sec}$. A ventral midline incision was made, and the diaphragm was removed and frozen $\left(-80^{\circ} \mathrm{C}\right)$. The en bloc cervical (C3-C6) and thoracic (T3-T6) spinal cords were harvested based on the anatomical location of the ventral rootlets and rapidly placed on a freezing microtome $\left(-32^{\circ} \mathrm{C}\right)$. The dorsal spinal cord was removed in successive $50 \mu \mathrm{m}$ sections until the ventral aspect of the central canal was seen. Tissues were stored at $-80^{\circ} \mathrm{C}$ until neurotrophic protein concentrations were assessed.

Protein determination (ELISA). Following the protocols described by Okragly and Haak-Frendscho (1997), tissue extracts were prepared. Tissue samples were weighed and homogenized in cold extraction buffer (Tris-buffered saline, $\mathrm{pH} 8.0$, with $1 \%$ NP-40, $10 \%$ glycerol, $0.5 \mathrm{~mm}$ sodium metavanadate, $1 \mathrm{~mm}$ PMSF, $10 \mu \mathrm{g} / \mathrm{ml}$ aprotinin, and $1 \mu \mathrm{g} / \mathrm{ml}$ leupeptin). The homogenates were acidified to $\mathrm{pH} \sim 3.0$ with $1 \mathrm{~N} \mathrm{HCl}$, incubated at room temperature for $15 \mathrm{~min}$, and neutralized with $1 \mathrm{~N}$ $\mathrm{NaOH}$ to $\mathrm{pH} \sim 7.6$. The $\mathrm{pH}$ was determined by measuring a drop of the homogenates on $\mathrm{pH}$ paper. After acid treatment, the homogenates were microfuged at $7000 \times g$ for $10 \mathrm{~min}$, and the supernatants were assayed by sandwich ELISA.

Commercially available antibody sandwich ELISAs (Promega, Madison, WI) were used for the detection of BDNF (TB 257), NT-3 (TB 243), GDNF (TB 221), and TGF- $\beta_{1}$ (TB 196) in the tissue homogenate supernatants.

Statistical analysis. Reported values are expressed as picograms per gram of tissue wet weight. Statistical significance was assessed using a one-way ANOVA followed by a Student-Newman-Keuls post hoc test for multiple comparisons between treatment groups (SigmaStat; Jandel Scientific Software, San Rafael, CA). $p<0.05$ was considered significant. Dixon's $Q$ test (Rohrbacher, 1991) was used to detect outliers in the BDNF concentrations of thoracic spinal cords in control rats. On this basis, two data values were excluded from analysis.

To localize CDR-induced changes in BDNF and NT-3 within the ventral spinal cord, immunohistochemistry was performed. Rats were deeply anesthetized with sodium pentobarbital $(75 \mathrm{mg} / \mathrm{kg}$, i.p. ) for transcardiac perfusion with $2 \%$ (BDNF) or $4 \%$ (NT-3) paraformaldehyde. Spinal cords were removed, post-fixed for $3 \mathrm{hr}$, and cryoprotected in $20 \%$ sucrose and $5 \%$ glycerin $\left(4^{\circ} \mathrm{C}\right)$. Coronal sections $(50 \mu \mathrm{m})$ were cut on a freezing microtome and immediately processed for BDNF or NT-3 immunoreactivity following the antibody suppliers' recommendations with slight alterations as follows.

Free-floating sections processed for BDNF immunoreactivity were washed in Earl's buffered salt solution (EBSS) with $0.1 \%$ saponin (wash solution, $\mathrm{pH}$ 7.2-7.4) and incubated for $45 \mathrm{~min}$ in EBSS containing $0.1 \%$ saponin, $3 \mathrm{~m}$ sodium azide, and 1\% hydrogen peroxide. Sections processed for NT-3 immunoreactivity were washed in 0.1 м PBS, pH 7.2-7.4, and incubated for $45 \mathrm{~min}$ in $0.3 \%$ hydrogen peroxide. Endogenous biotin was then blocked for $30 \mathrm{~min}$ with an avidin-biotin blocking kit (Vector Laboratories, Burlingame, CA). Staining was performed by incubating sections with primary anti-BDNF antibodies $(5 \mu \mathrm{g} / \mathrm{ml}$ for $12 \mathrm{hr}$ at room temperature; R\&D Systems, Minneapolis, MN) or anti-NT-3 antibodies ( $2 \mu \mathrm{g} / \mathrm{ml}$ for $24-48 \mathrm{hr}$ at $4^{\circ} \mathrm{C}$; R\&D Systems), with secondary antibodies (BDNF, biotinylated goat anti-mouse; NT-3, biotinylated rabbit antigoat; Vector Laboratories) for $45 \mathrm{~min}$, and with an avidin-biotinperoxidase reagent (1:500 dilution, ABC Elite; Vector Laboratories) for $30 \mathrm{~min}$. Sections were then reacted with a solution containing $0.04 \%$ diaminobenzidine tetrahydrochloride, $0.01 \%$ hydrogen peroxide, and $0.14 \%$ nickel chloride in EBSS.

\section{RESULTS}

Comparisons of neurotrophic protein concentrations were made between three harvested tissues: (1) the ventral cervical spinal cord corresponding to the deafferented segments (C3-C6), (2) the diaphragm, because neurotrophic factors may be retrogradely transported to motoneurons (Curtis et al., 1998), and (3) the ventral thoracic spinal cord from T3-T6, an area that provides motor innervation of the inspiratory intercostal muscles. Because the concentrations of neurotrophic factors were not significantly different between sham-operated and unoperated control rats in any tissue studied, with or without inclusion of statistical outliers, the data from these groups were pooled (data not shown). Thus, the stress of sham surgery and recovery was not sufficient to alter the expression of any protein studied. Differences in the concentrations of neurotrophic factors from rhizotomized versus control rats result specifically from chronic deafferentation of the cervical spinal segments.

CDR significantly increased BDNF levels in the ventral cervical cord versus the sham-operated and unoperated control group $(110 \%, p=0.002$; Fig. $1 a)$. In contrast, BDNF levels in the ventral thoracic spinal cord or diaphragm were unchanged by rhizotomy (Fig. 1a). In the sham-operated and control rats, two measurements of BDNF concentration in the control thoracic spinal segments were excluded from analysis because they qualified as statistical outliers $(Q=0.913)$. When the two outlying values were included in the data, the results of statistical analysis were similar: there were still no statistically significant differences in ventral thoracic BDNF concentration between CDR and shamoperated and control rats $(1225 \pm 451$ vs $526 \pm 55 \mathrm{pg} / \mathrm{gm}$ of tissue; $p=0.21$ ).

CDR significantly increased NT-3 concentration in the ventral cervical spinal cord $(100 \%, p=0.002)$ when compared with control rats (Fig. 1b). NT-3 was also increased significantly in the ventral thoracic spinal cord $(98 \%, p=0.009)$, although not in the diaphragm (Fig. 1b).

The concentrations of GDNF and TGF- $\beta 1$ were not altered by CDR in any tissue (Figs. 2a,b).

Figure 3 shows representative photomicrographs of the ventral spinal cord at $\mathrm{C} 4$ from two different CDR rats. Cross-sectional neuronal areas were crudely estimated from radial measurements of the cell body made with an eyepiece redicule and based on a spherical model. Strong BDNF immunostaining was seen in the ventral cervical spinal cord and was localized in a selective population of neurons, the majority being $\sim 300-900 \mu \mathrm{m}^{2}$ in area 

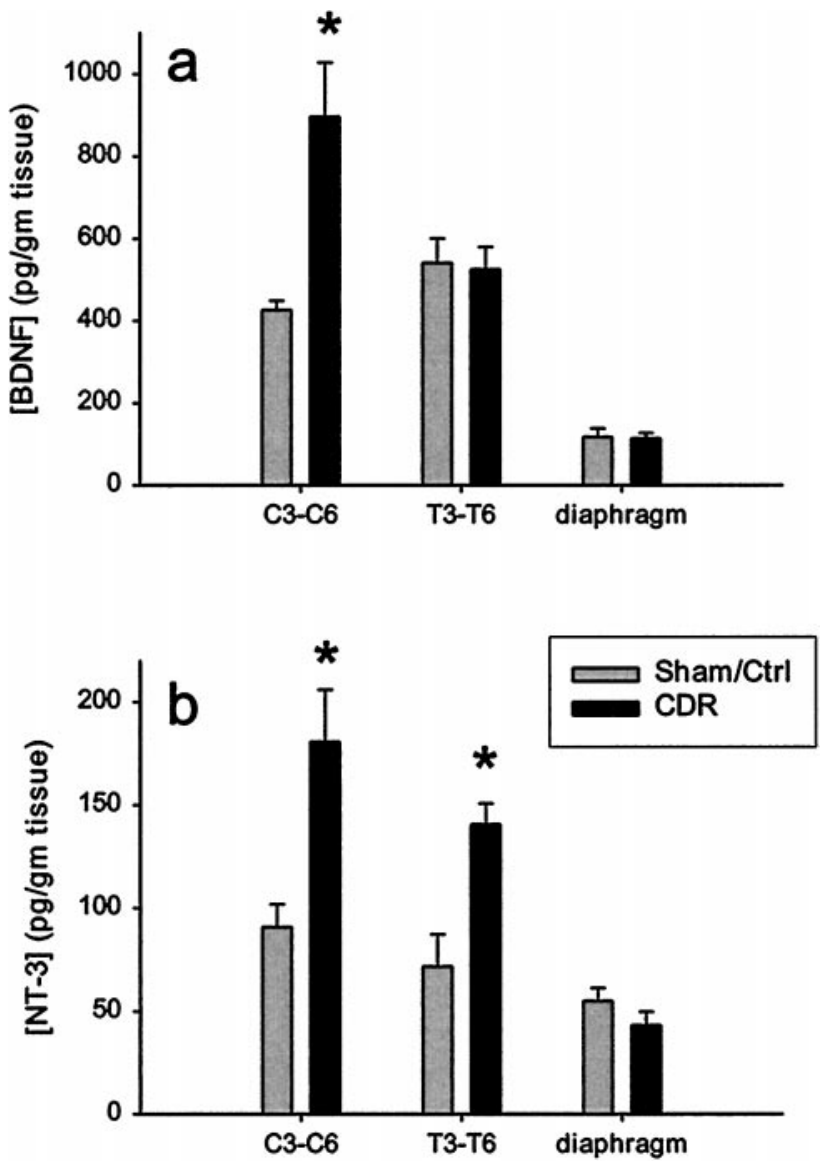

Figure 1. Effects of CDR on BDNF and NT-3 concentrations in the ventral spinal cord. $a$, CDR significantly increased BDNF levels in the ventral cervical cord versus sham-operated and unoperated control rats but not in the ventral thoracic spinal cord or diaphragm. $b$, CDR significantly increased NT-3 concentrations in the ventral cervical and thoracic spinal cord versus control rats but not in the diaphragm. Black bars, CDR; gray bars, control rats (sham or unoperated). ${ }^{*} p<0.05$ indicates a significant value different from control.

(Fig. 3a, magnification, $400 \times$ ). Labeling was seen within the soma and nuclei of cells, although little BDNF protein was observed in the white matter, glial cells, dendritic processes, or axons (Fig. $3 a$ ). NT-3 was also localized in a selective population of neurons within the ventral cervical and thoracic spinal cords with approximately the same area as those labeled with BDNF $(\sim 300-900$ $\mu \mathrm{m}^{2}$; Fig. 3b, magnification, $\left.400 \times\right)$. However, NT-3 was also found within dendritic processes, as well as in axons within the white and gray matter. Some very small cells within the white matter $\left(\sim 7-20 \mu \mathrm{m}^{2}\right)$, presumably glial cells, were also NT-3immunoreactive (results not shown). Neither BDNF nor NT-3 immunoreactivity could be detected in terminals or varicosities, suggesting that neither protein was localized in descending fibers.

\section{DISCUSSION}

The results indicate that cervical spinal deafferentation increases BDNF and NT-3 protein concentrations within neurons of the ventral spinal cord. NT-3 changes occur in both the affected spinal segments (i.e., cervical), and in distant, functionally related regions of the spinal cord (i.e., rostral thoracic). Although a causal relationship has not been established, these data provide suggestive evidence that BDNF and NT-3 may play a role in spinal plasticity attendant to CDR: increased serotonin terminal density
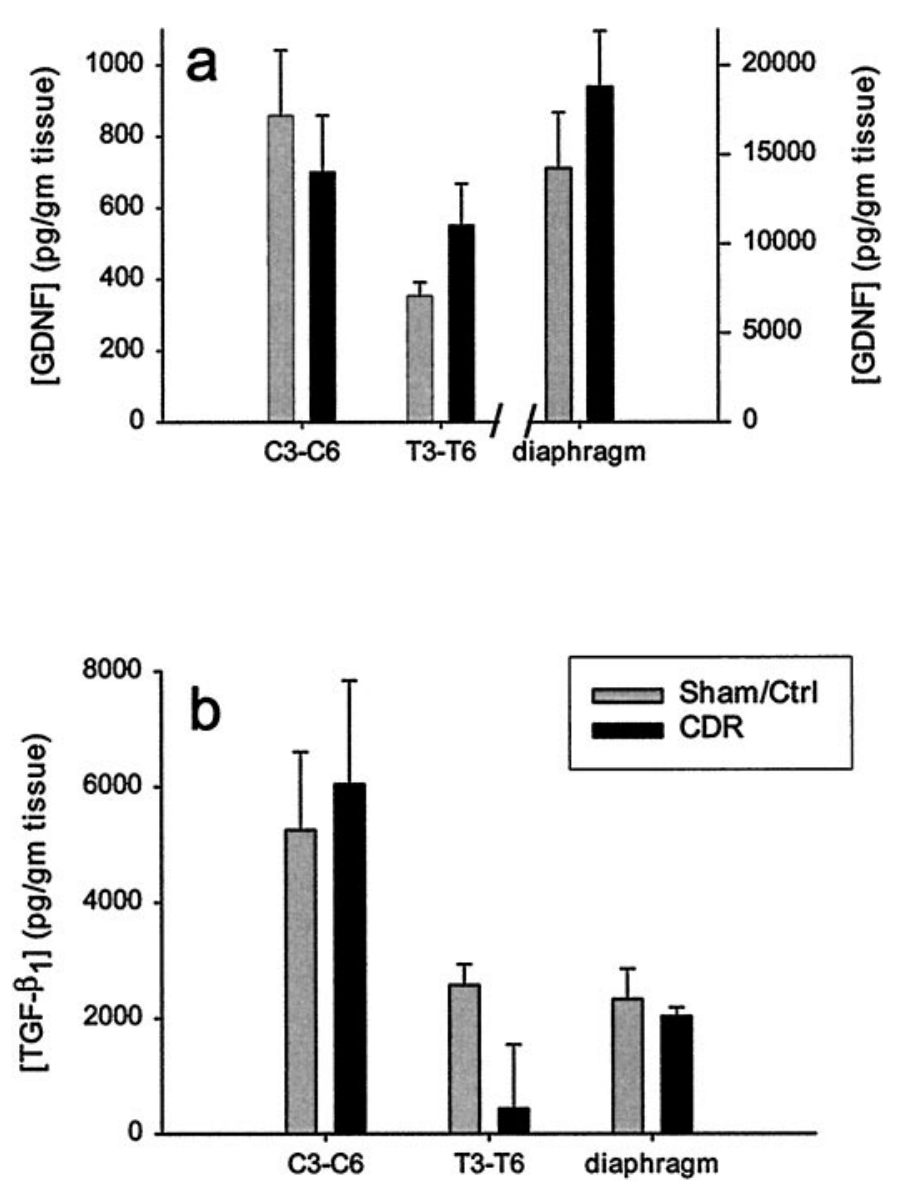

Figure 2. Effects of CDR on GDNF and TGF- $\beta_{1}$ concentrations in the ventral spinal cord. Neither GDNF nor TGF- $\beta_{1}$ concentrations were affected by cervical dorsal rhizotomy in any tissue examined $(a, b)$. Black bars, CDR; gray bars, control rats (sham or unoperated).

in the immediate vicinity of phrenic motoneurons and enhanced serotonin-dependent long-term facilitation of phrenic motor output after episodic hypoxia (Kinkead et al., 1998). BDNF and NT-3 have many of the requisite characteristics to mediate such plasticity.

BDNF exerts reciprocal effects on serotonergic neurons within the CNS. For example, serotonin modulates BDNF mRNA in the CNS (Zetterström et al., 1999), possibly via 5- $\mathrm{HT}_{2 \mathrm{~A}}$ receptors (Vaidya et al., 1997, 1999). In addition, exogenous BDNF reduces neurotoxin-induced loss of cortical 5-HT axons and promotes sprouting of 5-HT axons (Mamounas et al., 1995, 2000). Thus, BDNF has the potential to play a role in the increased serotonergic innervation of the phrenic motor nucleus after CDR (Kinkead et al., 1998).

Increased BDNF and NT-3 expression may represent a common response to a variety of spinal insults or changing conditions, acting to promote survival and/or increase the function of the affected motoneurons by initiating mechanisms of plasticity. For example, systemic administration of the glutamate agonist kainic acid results in experimentally induced seizures and dramatically increases spinal BDNF mRNA levels (Scarisbrick et al., 1999). Similarly, BDNF mRNA is elevated in the lumbar spinal cord after 1-5 d of treadmill exercise, suggesting another model of activity-dependent increases in neurotrophin expression (GómezPinilla et al., 1999). Our results may also represent a form of activity-dependent neurotrophin expression. Diaphragmatic af- 

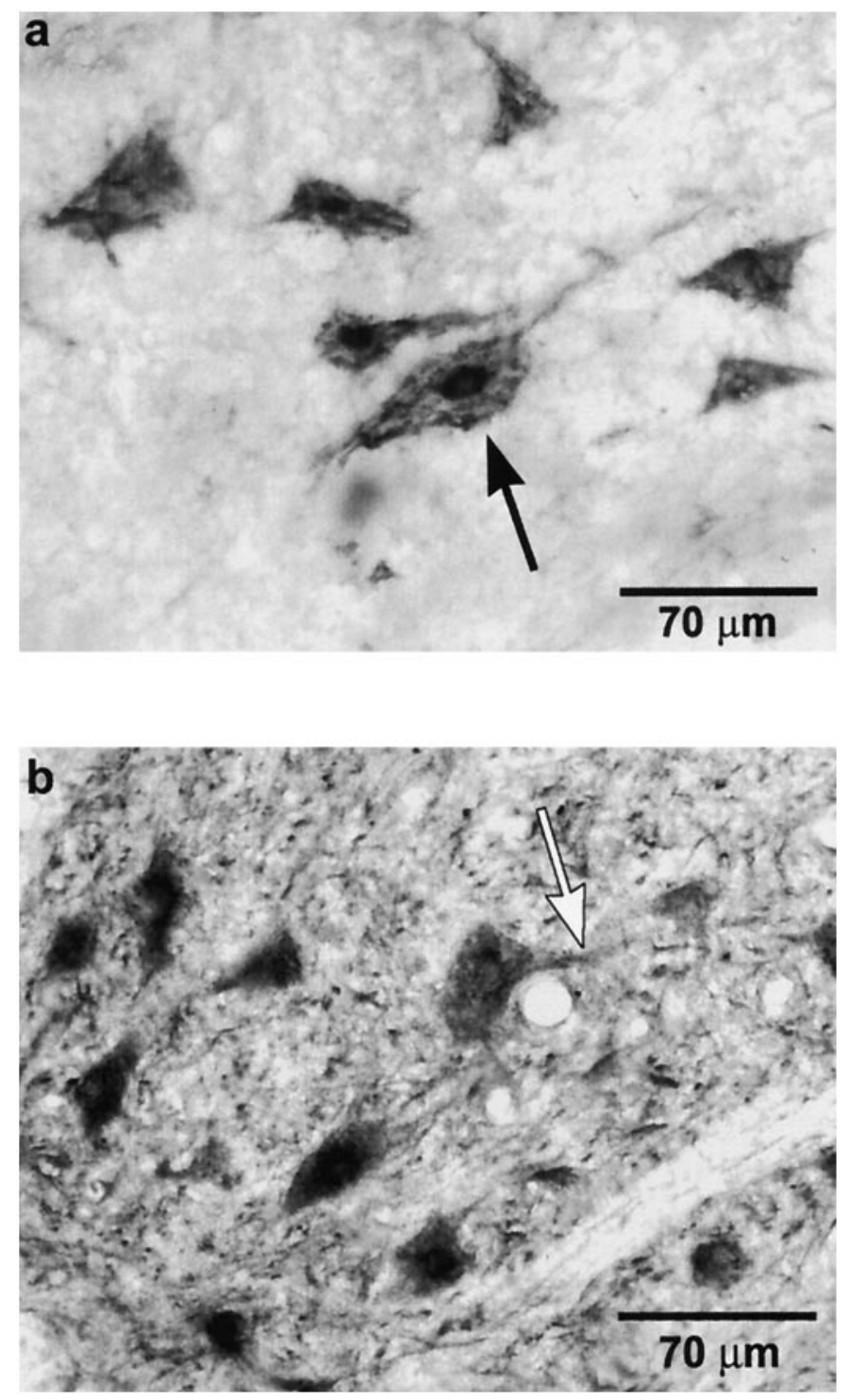

Figure 3. Photomicrographs of immunohistochemical reaction products for BDNF $(a)$ and NT-3 $(b)$ in the C4 ventral horn from two CDR rats. BDNF was primarily localized within neurons of the ventral spinal cord. Size and location suggest that these neurons include both motoneurons and interneurons; however, only presumed motoneurons (based on neuronal area) are seen at this magnification (a, black arrow; magnification, $400 \times)$. BDNF localized mainly to the cytoplasm and nuclei, with little staining observed in white matter, dendritic processes, nerve terminals, or nerve fibers. A similar pattern of localization was seen for NT-3 immunoreactivity; the majority of NT-3 protein was detected within neurons ( $b$; magnification, $400 \times$ ). However, NT-3 was also observed within dendritic processes (white arrow), as well as in axons within the white and gray matter. Some very small cells within the white matter, presumably glial cells, were also labeled with the NT-3 antibody (results not shown).

ferent neurons are primarily inhibitory to phrenic motor output (Speck and Revelette, 1987; Marlot et al., 1988). Thus, CDR is expected to release the respiratory system from tonic or periodic inhibition, thereby enhancing activity in selected neural populations.

Increased NT-3 expression in ventral thoracic segments associated with inspiratory intercostal activity was somewhat surprising, although not without precedent. Thoracic dorsal rhizotomy from $\mathrm{T} 3$ to $\mathrm{T} 12$ in a caprine model augments serotonin concen- tration in cervical spinal segments associated with the phrenic motor nucleus in goats but not directly affected by the surgery (Mitchell et al., 1995; Turner et al., 1997). Intercostal motoneurons providing motor output to (inspiratory) parasternal intercostal muscles are located primarily in rostral thoracic segments (DeTroyer et al., 1999). Expiratory activity becomes more prevalent in the lower (caudal) thoracic segments (Larnicol et al., 1982; DeTroyer et al., 1999). Although neurophysiological data from the intercostal muscles are not available, increased NT-3 in the ventral thoracic spinal cord may be associated with enhanced respiratory motor output to the inspiratory intercostal muscles, thereby preserving respiratory function after CDR. Collectively, these observations provide evidence that sensory deafferentation can elicit neurochemical plasticity in multiple, functionally related areas of the spinal cord. This finding raises the possibility that one form of functional compensation (apart from compensation at the site of injury or denervation) is to upregulate function in complementary neural structures that consequently assume a greater contribution to the task at hand, in this case breathing.

The distribution of BDNF and NT-3 immunolabeling in this study is consistent with previously published results (Kawamoto et al., 1998; Dreyfus et al., 1999) and indicates that the majority of BDNF and NT-3 in the ventral horn of the spinal cord is found within cell bodies, although it appeared to be located in both motoneurons and interneurons. However, the sources of BDNF and NT-3 protein are not entirely clear. Both BDNF and NT-3 can be anterogradely (Altar and DiStefano, 1998) and retrogradely (Curtis et al., 1998) transported in the CNS. Studies showing that BDNF and NT-3 mRNAs are expressed within spinal motoneurons (Scarisbrick et al., 1999) provide suggestive evidence that these neurotrophic factors may be produced within the motoneurons and/or interneurons per se. Because we saw little evidence for increased fiber or terminal labeling after CDR, it does not appear that the increased neurotrophin levels originated at distant, descending neural systems such as the raphe nuclei or locus coeruleus. Furthermore, the proteins do not appear to have been retrogradely transported from the diaphragm, because diaphragm concentrations were unaffected by CDR.

We chose to study responses of the ventral cervical spinal cord to deafferentation because this is an area that is critical to respiratory motor control. Although little is known concerning neurotrophic factors and respiratory motor control, BDNF is required for survival and the development of normal breathing behavior (Erickson et al., 1996; Balkowiec and Katz, 1998). BDNF null mutants (bdnf ${ }^{-/-}$) lack BDNF-dependent primary sensory neurons that link the carotid body and brainstem and, as a result, exhibit pronounced respiratory depression, resulting in death shortly after birth (Hertzberg et al., 1994; Erickson et al., 1996). We speculate that spinal BDNF may also be important in the respiratory function of adult mammals. For example, BDNF might play a critical modulatory role in circumstances in which the respiratory control system has been compromised, allowing a degree of plasticity in the system that allows for a continual adjustment to changing physiological or environmental conditions.

In summary, an upregulation of BDNF and NT-3 protein concentration within the ventral cervical spinal cord may exert trophic influences on phrenic motoneurons and/or serotonergic neurons that innervate the phrenic motor nucleus. Our studies provide novel, suggestive evidence that neurotrophins underlie serotonin-dependent plasticity in (spinal) respiratory motor control and, thereby, implicate BDNF and NT-3 more generally in 
mechanisms of spinal plasticity, possibly after spinal injury. Because dorsal rhizotomy may be regarded as a form of selective spinal injury, we speculate that induced changes in spinal neurotrophins may yield insights into natural, compensatory mechanisms operative during more severe spinal injuries.

\section{REFERENCES}

Altar CA, DiStefano PS (1998) Neurotrophin trafficking by anterograde transport. Trends Neurosci 21:433-437.

Balkowiec A, Katz DM (1998) Brain-derived neurotrophic factor is required for normal development of the central respiratory rhythm in mice. J Physiol (Lond) 510:527-533.

Cabelli RJ, Hohn A, Shatz CJ (1995) Inhibition of ocular dominance column formation by infusion of NT-4/5 or BDNF. Science 267:1662-1666.

Calia E, Persico AM, Baldi A, Keller F (1998) BDNF and NT-3 applied in the whisker pad reverse cortical changes after peripheral deafferentation in neonatal rats. Eur J Neurosci 10:3194-3200.

Curtis R, Tonra JR, Stark JL, Adryan KM, Park JS, Cliffer KD, Lindsay RM, DiStefano PS (1998) Neuronal injury increases retrograde axonal transport of the neurotrophins to spinal sensory neurons and motor neurons via multiple receptor mechanisms. Mol Cell Neurosci 12:105-118.

DeLeo JA, Colburn RW, Rickman AJ (1997) Cytokine and growth factor immunohistochemical spinal profiles in two animal models of mononeuropathy. Brain Res 759:50-57.

DeTroyer A, Legrand A, Wilson TA (1999) Mechanical advantage of the canine external and internal intercostal muscles. FASEB J 13:A498.

Dreyfus CF, Dai X, Lercher LD, Racey BR, Friedman WJ, Black IB (1999) Expression of neurotrophins in the adult spinal cord in vivo. J Neurosci Res 56:1-7.

Edgerton VR, Roy RR, Hodgson JA, Prober RJ, deGuzman CP, deLeon R (1992) Potential of adult mammalian lumbosacral spinal cord to execute and acquire improved locomotion in the absence of supraspinal input. J Neurotrauma 9:S119-S128.

Elliott JL, Snider WD (1996) Motor neuron growth factors. Neurology 47:S47-S53.

Erickson JT, Conover JC, Borday V, Champagnat J, Barbacid M, Yancopoulos G, Katz DM (1996) Mice lacking brain-derived neurotrophic factor exhibit visceral sensory neuron losses distinct from mice lacking NT4 and display a severe developmental deficit in control of breathing. J Neurosci 16:5361-5371.

Glazner GW, Mu X, Springer JE (1998) Localization of glial cell linederived neurotrophic factor receptor alpha and c-ret mRNA in rat central nervous system. J Comp Neurol 391:42-49.

Gómez-Pinilla F, Ying L, Roy RR, Edgerton VR (1999) Neuromuscular activity induces the expression of brain-derived neurotrophic factor (BDNF) in the spinal cord and muscle. Soc Neurosci Abstr 25:514.

Goshgarian HG, Guth L (1977) Demonstration of functionally ineffective synapses in the guinea pig spinal cord. Exp Neurol 57:613-621.

Hertzberg T, Fan G, Finley JCW, Erickson JT, Katz DM (1994) BDNF supports mammalian chemoafferent neurons in vitro and following peripheral target removal in vivo. Dev Biol 166:801-811.

Johnson H, Hokfelt T, Ulfhake B (1996) Decreased expression of TrkB and TrkC mRNAs in spinal motoneurons of aged rats. Eur $\mathbf{J}$ Neurosci 8:494-499.

Kang H, Shuman EM (1995a) Long-lasting neurotrophin-induced enhancement of synaptic transmission in the adult hippocampus. Science 267:1658-1662.

Kang HJ, Shuman EM (1995b) Neurotrophin-induced modulation of synaptic transmission in the adult hippocampus. J Physiol (Paris) 89:11-22.

Kawamoto Y, Nakamura S, Akiguchi I, Kimura J (1998) Immunohistochemical localization of brain-derived neurotrophic factor in the spinal cords of amyotrophic lateral sclerosis and non-amyotrophic lateral sclerosis patients. J Neuropathol Exp Neurol 57:822-830.

Kinkead R, Zhan WZ, Prakash YS, Bach KB, Sieck GC, Mitchell GS (1998) Cervical dorsal rhizotomy enhances serotonergic innervation of phrenic motoneurons and serotonin-dependent long-term facilitation of respiratory motor output in rats. J Neurosci 18:8436-8443.

Larnicol N, Rose D, Marlot D, Duron B (1982) Spinal localization of the intercostal motoneurones innervating the upper thoracic spaces. Neurosci Lett 31:13-18.
Liou WW, Goshgarian HG (1997) The superimposed effects of chronic phrenicotomy and cervical spinal cord hemisection on synaptic cytoarchitecture in the rat phrenic nucleus. Exp Neurol 145:258-267.

Mamounas LA, Blue ME, Siuciak JA, Altar CA (1995) Brain-derived neurotrophic factor promotes the survival and sprouting of serotonergic axons in rat brains. J Neurosci 15:7929-7939.

Mamounas LA, Altar CA, Blue ME, Kaplan DR, Tessarollo L, Lyons WE (2000) BDNF promotes the regenerative sprouting, but not survival, of injured serotonergic axons in the adult rat brain. J Neurosci 20:771-782

Marlot D, Macron JM, Duron B (1988) Effects of ipsilateral and contralateral cervical phrenic afferents stimulation on phrenic motor unit activity in the cat. Brain Res 450:373-377.

Mitchell GS, Foley KT, Martin PA, Olson EB, Miletic V, Brownfield MS (1995) Increased spinal monoamine concentrations following thoracic dorsal rhizotomy (TDR) in goats. Soc Neurosci Abstr 21:1886.

Moreno DE, Yu X-J, Goshgarian HG (1992) Identification of the axon pathways which mediate functional recovery of a paralyzed hemidiaphragm following spinal cord hemisection in the adult rat. Exp Neurol 116:219-228

Neumann S, Woolf CJ (1999) Regeneration of dorsal column fibers into and beyond the lesion site following adult spinal cord injury. Neuron 23:83-91.

Okragly AJ, Haak-Frendscho M (1997) An acid-treatment method for the enhanced detection of GDNF in biological samples. Exp Neurol 145:592-596.

Randic M (1996) Plasticity of excitatory synaptic transmission in the spinal cord dorsal horn. Prog Brain Res 113:463-506.

Rohrbacher DB (1991) Statistical treatment for rejection of deviant values of Dixon's "Q" parameter and related subrange ratios at the $95 \%$ confidence level. Anal Chem 63:139-146.

Rossi FM, Bozzi Y, Pizzorusso T, Maffei L (1999) Monocular deprivation decreases brain-derived neurotrophic factor immunoreactivity in the rat visual cortex. Neuroscience 90:363-368.

Scarisbrick IA, Isackson PJ, Windebank AJ (1999) Differential expression of brain-derived neurotrophic factor, neurotrophin-3, and neurotrophin- $4 / 5$ in the adult rat spinal cord: regulation by the glutamate receptor agonist kainic acid. J Neurosci 18:7757-7769.

Sherwood NT, Lo DC (1999) Long-term enhancement of central synaptic transmission by chronic brain-derived neurotrophic factor treatment. J Neurosci 19:7025-7036.

Singh TD, Mizuno K, Kohno T, Nakamura S (1997) BDNF and trkB mRNA expression in neurons of the neonatal mouse barrel field cortex: normal development and plasticity after cauterizing facial vibrissae. Neurochem Res 22:791-797.

Speck DF, Revelette WR (1987) Attenuation of phrenic motor discharge by phrenic nerve afferents. J Appl Physiol 62:941-945.

Turner DL, Bach KB, Martin PA, Olson EB, Brownfield M, Foley KT, Mitchell GS (1997) Modulation of ventilatory control during exercise. Respir Physiol 110:277-285.

Vaidya VA, Marek GJ, Aghajanian GK, Duman RS (1997) $5-\mathrm{HT}_{2 \mathrm{~A}}$ receptor-mediated regulation of brain-derived neurotrophic factor mRNA in the hippocampus and the neocortex. J Neurosci 17:2785-2795.

Vaidya VA, Terwilliger RZ, Duman RS (1999) Role of 5-HT $\mathrm{H}_{2 \mathrm{~A}}$ receptors in the stress-induced down-regulation of brain-derived neurotrophic factor expression in rat hippocampus. Neurosci Lett 262:1-4.

Yamamoto M, Sobue G, Yamamoto K, Terao S, Mitsuma T (1996) Expression of mRNAs for neurotrophic factors (NGF, BDNF, NT-3, and GDNF) and their receptors ( $75^{\mathrm{NGFR}}$, TrkA, TrkB, and TrkC) in the adult human peripheral nervous system and nonneural tissues. Neurochem Res 21:929-938.

Zetterström TSC, Pei Q, Madhav TR, Coppell AL, Lewis L, GrahameSmith DG (1999) Manipulations of brain 5-HT levels affect gene expression for BDNF in rat brain. Neuropharmacology 38:1063-1073.

Zhan WZ, Zhan P, Prakash YS, Smithson K, Mitchell GS, Sieck GC (1997) Cervical dorsal rhizotomy (CDR) enlarges phrenic motoneurons in rats. FASEB J 11:A206.

Zhang B, Goldberger ME, Murray M (1993) Proliferation of SP- and 5HT-containing terminals in lamina II of rat spinal cord following dorsal rhizotomy: quantitative EM-immunocytochemical studies. Exp Neurol 123:51-63. 